\title{
MAHARAAS: SRI SRI GOVINDAJI TEMPLE AND OTHER LOCAL TEMPLES OF MANIPUR
}

\author{
Laishram Hemantakumari Devi ${ }^{* 1}$ 洒 \\ ${ }^{* 1}$ Research Scholar in Manipuri Dance, Department of Rabindra Sangit, Dance and Drama, Sangit- \\ Bhavana, Visva-Bharati University, Santiniketan, India
}

DOI: https://doi.org/10.29121/granthaalayah.v9.i2.2021.3654

Article Type: Research Article

Article Citation: Laishram Hemantakumari Devi. (2021). MAHARAAS: SRI SRI GOVINDAJI TEMPLE AND OTHER LOCAL TEMPLES OF MANIPUR. International Journal of Research GRANTHAALAYAH, 9(2), 299-308. https://doi.org/10.29121/granthaa layah.v9.i2.2021.3654

Received Date: 01 February 2021

Accepted Date: 28 February 2021

Keywords:

Maharaas

Manipur

Temple

\begin{abstract}
Manipur literally meaning "A Jeweled land" nestle deep within a lush green corner of North East India. It is known to the world through its dances. Its most important feature is the close association of religion with music and dance. The distinctive approach to culture is best seen in the fact that dance is religious and its aim a spiritual experience. Dances are devotional or ritualistic rather than entertainment of the eyes. The coming of Hinduism in Manipur created a deep impact in the society. It touched each and every aspect of life affecting the rituals, beliefs, customs and traditions of the entire Meitei worldview. There was a major impact on literature, architecture and performing arts - dance and music etc.
\end{abstract}

\section{INTRODUCTION}

The formal initiation of the king Garibaniwaz to Vaishnavism took place by the beginning of the $18^{\text {th }}$ century and the king declared Hinduism as the state religion. During his reign the 'Ariba Pala' (earliest Nata Pala group) became the predominant ritual for propitiating the God Rama.

Maharaj Bhagyachandra was a remarkable King among the Kings of Manipur. In 1765 A.D. Bhagyachandra was defeated by Hsinbyusin, the son of the great Burmese king Alungpaya and he fled to Cachar in Assam with some of his followers. Then he took refuge in the court of the Assamese king Swargadeva Rajeshwar Singh at Tekhao. With the help of the Ahom king, Bhagyachandra regained the kingdom of Manipur in 1768.

After the restoration of his land from the enemies, the king offered the first ever Raasleela to Sri Sri Govindaji which was carved out of a jack tree from the Kaina hill and it was inaugurated on friday, the $11^{\text {th }}$ day of Hiyangei, 1779 A.D., sakabda 1701 at the palace of Langthabal for five consecutive days. As per the opinions expressed by different writers, scholars, gurus and renowned personalities, it is assumed that the first Raas was regarded as 'Maharaas'.

Dr. Jamini's Cultural History of Manipur: Sija Laioibi and the Maharaas writes that: "In 1779 (shakabda 1709), King Rajarshi Bhagyachandra inaugurated Shri Govinda. The Maharaas dance was dedicated on this occasion. The princess played the role of Radhika. She was eight years old at the time. Since she was already well versed in music

(C) 2021 The Author(s). This is an open access article distributed under the terms of the Creative Commons Attribution License, which permits unrestricted use, distribution, and reproduction in any medium, provided the original author and source are credited. 
and dance, her performance in the Rasa dance was a great success and well applauded. It is said that she took the role of Radhika, she was the "Bimba" (shadow) of Radhika, and thus she came to be known as Bimbabati".

The king firmly believed that Sankirtana is the foremost religion in the Kaliyuga. Before the start of the Raas, Sankirtana was offered by the Nupa-Pala. Since then, the continuous succession of such practice of beginning Sankirtana by the Nupa-Pala is prevalent till now. Thus, the emergence of Nata Sankirtana and Maharaas became the vivid example of Hinduizing art forms in Manipur.

\section{PHILOSOPHY OF MAHARAAS}

The Maharaas Leela is based on the Raas Panchadhyay of Srimad Bhagavata of Maha Kavi Veda Vyas. Sri Sri Raas Panchadhyay is known as the combination of five adhyays viz. $29^{\text {th }}, 30^{\text {th }}, 31^{\text {st }}, 32^{\text {nd }}$ and $33^{\text {rd }}$ adhyays included in the Dasham (10 ${ }^{\text {th }}$ Skandha of the great purana of 'Srimad Bhagavata'. It is an adhyay composed in description of the Raasleela played by the Lord Sri Krishna with those gopis of Vrindavan who practice the worship of goddess Katyayani. The saint Sukadev, son of the sage Veda Vyas narrated to Parikshit Maharaj the contents of Raasleela in the Dasham skandha of Srimad Bhagavata Mahapurana are enumerated as follows:

(A) 29th ADHYAY (DISCOURSE OR PART XXIX)

A description of the celebrated Rasa Play of the Lord

(B) 30th ADHYAY (DISCOURSE OR PART XXX)

The Gopis' quest for Sri Krsna during the Rasa Play

(C) $31^{\text {st }}$ ADHYAY (DISCOURSE OR PART XXXI)

The Gopis' song at the Lord's disappearance during the Rasa Play

(D) 32nd ADHYAY (DISCOURSE OR PART XXXII)

The Lord comforts the Gopis during the Rasa play

(E) 33 ${ }^{\text {rd }}$ ADHYAY (DISCOURSE OR PART XXXIII)

\section{A description of the actual Rasa play}

The Saintly Vaishnavites regard these adhyay as the five souls of Lord Sri Krishna. If such five adhyay are heard with undivided attention it is believed that Moksha (salvation) is attained for the beings as such it is chanted by the Brahmins and Vaishnavites along with worship etc.

\section{SRI SRI GOVINDAJI TEMPLE}

The temple of Sri Sri Govindaji at the Palace Compound, Imphal, Manipur adjacent to the palace of former rulers of Manipur is a historic and sacred centre for the Vaishnavites is shown in figure No.1. It is a beautiful structure having a twin gold domes, a paved courtyard and a large congregation hall (mandapa). The presiding deities, Radha Govinda is flanked by idols of Lord Balaram and Krishna on the right side and idols of Lord Jaganath, Balabhadra and Subhadra on the left.

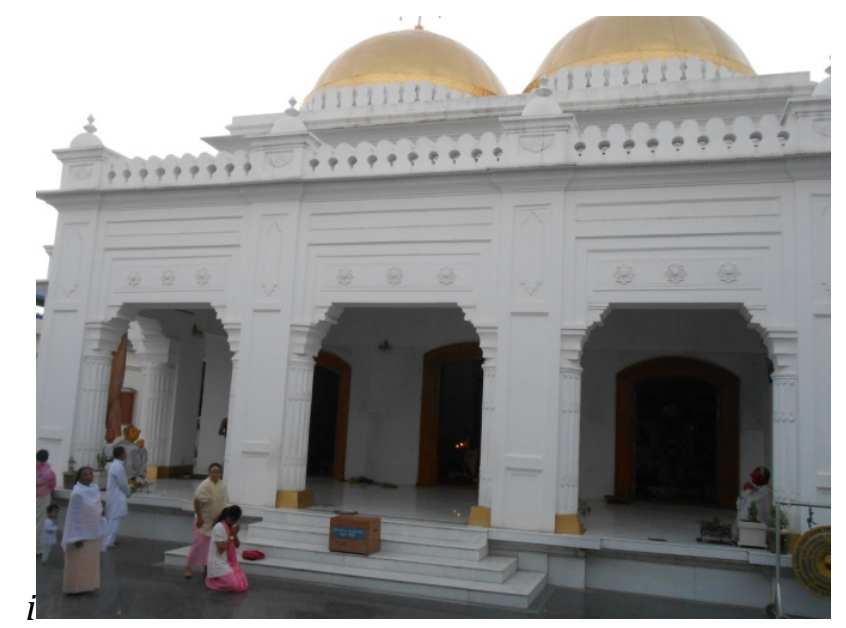

Figure 1: Sri Sri Govindaji Temple at Palace Compound, Imphal 


\section{RAASMANDAL OF SRI GOVINDAJI}

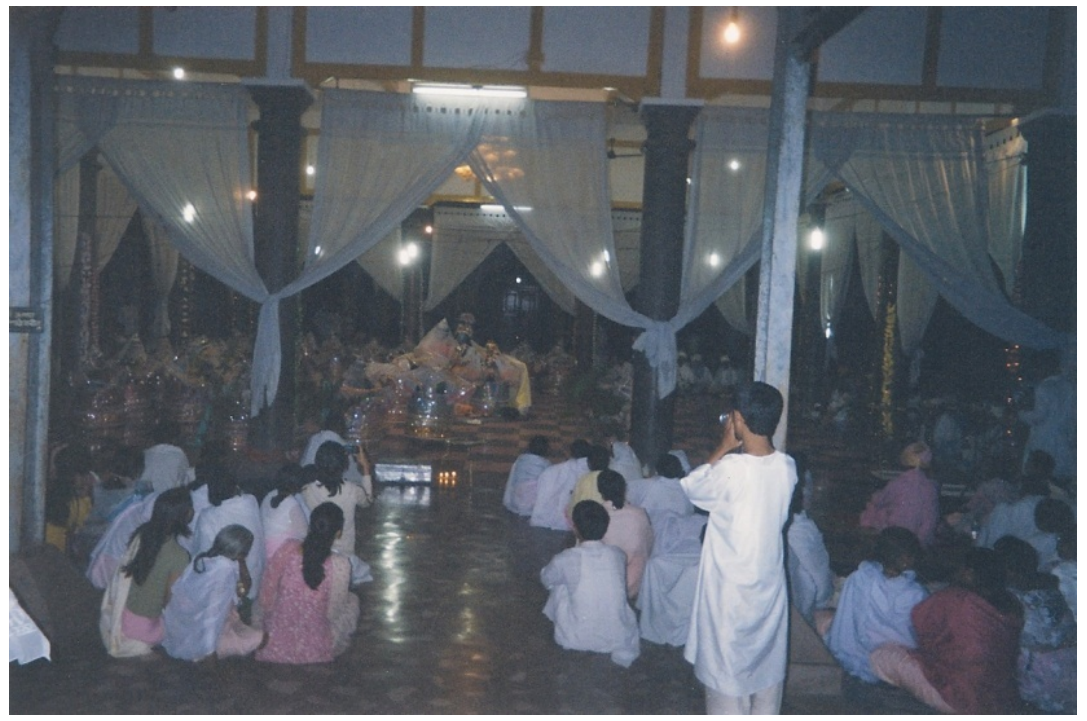

Figure 2: Raasmandal at Govindaji Temple

The Raasmandal in the centre of the mandapa has four gates in four directions is shown in figure No.2 . It is heavily decorated with flowers and creepers. In the centre there is a round movable 'Chakra' - pith (Bhadra chakra) for the consecration of the idols of Sri Govinda and Raseswari. The 'Chakra' will move along with the gopis when they dance in anti-clockwise direction. There is no 'Chakra'- pith in Raasleela performed in the villages where two artistes take the roles of Sri Govinda and Raseswari. The 12 inner posts of the Nata - Mandapa bordering the Raasmandal are generally covered with white cloths and these pillars support a big white canopy overhead covering the performing area. White colour is generally used at the time of worship and service to Sri Govinda. Sometimes the decoration of the Nata-mandapa is done with green leaves and branches of trees etc. There are twelve rounded stone masonry pillars about 16" dia each. The approximate consecutive inner distances between the pillars starting from the South west corner pillar towards the south-east corner are 11'9", 11'10" and 11'6" respectively. Similarly, the approx, consecutive inner distances between the pillars starting from the south west pillar towards the North-west corner measure as 11'6", 11'7" and 11'9" respectively. The opposite inner distances between the pillars against the above distances are almost the same. The Bhadra Chakra in the centre has a diameter of 5'6" approx.

\section{NUPA PALA (NIPA PALA) IN THE RAAS LEELA OF SRI SRI GOVINDAJI TEMPLE}

Before the moving out of Raseshwari Sri Govinda from the temple the performers of Nipa Pala bow down to Raseshwari Sri Govinda, Mandap mapu (presiding master of the ceremony), nobles, title holders, vaishnavas seated around the mandali, Pung yeiba (drum players), Esheihanba (leading singer), Duhar (assistant singer) and Arangpham (arranger) and then, as the artistes of Nipa pala make a round, the Brahmins will make Raseshwari Shri Govinda move out of the temple at the Mandali (Raasmandal).

For the raas of Sri Govindaji, before the beginning of Nipa Pala the idols of Raseshwari Shri Govinda will be placed in the centre of the raasmandal on the Bhadrachakra or chakra pith. After it is over, the Brahmin will sprinkle the holy water of conch to the devotees. The members of the Nipa pala will sort out their respective kokyet (Headdress) and put on their heads. They will kneel and wait for the Arangpham. The Arangpham will offer dhup thaomei (incense light), lei chandan (flower and sandal) and perform Boriba (offering the first white cloth) to the members of the Nipa pala is shown in figure No.3. 


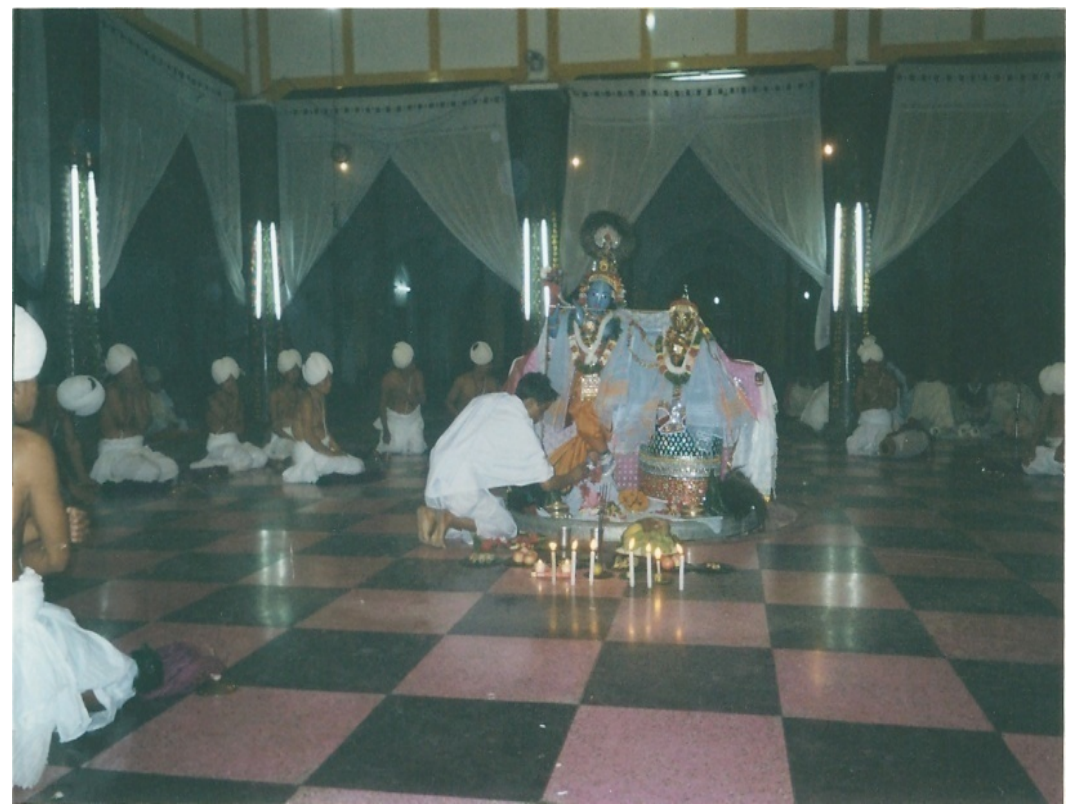

Figure 3: Sankirtana Nipa pala in Raas leela (Govindaji Temple)

The Thoubu (convener) on behalf of Govinda is entrusted to the father of the Makok chingbi (leading gopi). He will make a plea to start the ceremony with bowing down to the Nipa pala and the mandap mapu. Then the Brahmin Mandap Mapu will rise up and will pronounce the Hari Dhwani (sacred name of the Lord). Then it will be followed with Raga Achouba of pung, Eshei Raga (Raga of the song), Guru Vandana, Raga Taba, Nabadwip Varnan, Gouranga varnan - Gouranga Roop, Gouranga Bhabi etc, obeying the codes of Sankirtana Raga taba, Rajmen, Tanchap, Menkup, Betha. Then just after the Nipa pala have been seated, they will place their kokyet. The rasa of the song comes from the Gouranga bhavi to Vrindavan varnan (description of Vrindavan), the Raasdhari will bow to all the pung yeiba (drummers), esheihanba (lead singer), duhar and khonpangba (assistants) of the pala. It is an intimation for the Raas to be started soon.

The Mandap Mapu will show respect by bowing down towards all assembled around the mandap when the right time of starting Raas comes, the Brahmins after arrangement of offering varti (sacred burning light) is done, the Sutradharis will approach and bow down to the Sankirtana and also Raseshwari Shri Govinda being stationed at the 'Bhadra-chakra'. Again they will bow down to the mandap mapu, nobles and title holders, devotees and Vaishnav. Then the Nipa pala will conclude the sankirtana leaving to Vrindavan varnan. The Brahmins will light up the varti and offer aarti with the singing of Nipa pala.

Then the Raasdhari, Sutradhari, Flute player, Conch player, Esraj player will be offered lei-chandan and performed boriba with offering of white clothes and pana (betel leaf and nut) by the Arangpham. The Thoubu (convener) will bow down to those performers seated on the Sutra's area with a request to start the raas. Again he will bow down to all those including Mandap Mapu etc and in the western gate of mandali facing east he will kneel and be seated with folded hands.

\section{PERFORMANCE OF MAHARAAS IN THE TEMPLE OF SRI GOVINDAJI}

Every year on the Mera waphukpa, the full moon day of Hiyangei i.e. Kartika, the Maharaas Leela in its due order takes place at the temple of Sri Govindaji (Palace compound) is shown in figure No. 4 . The performance is done in the night. In the Maharaas, the main theme is performed with the singing of Raaspanchadhyay of Srimad Bhagavata Mahapurana. 


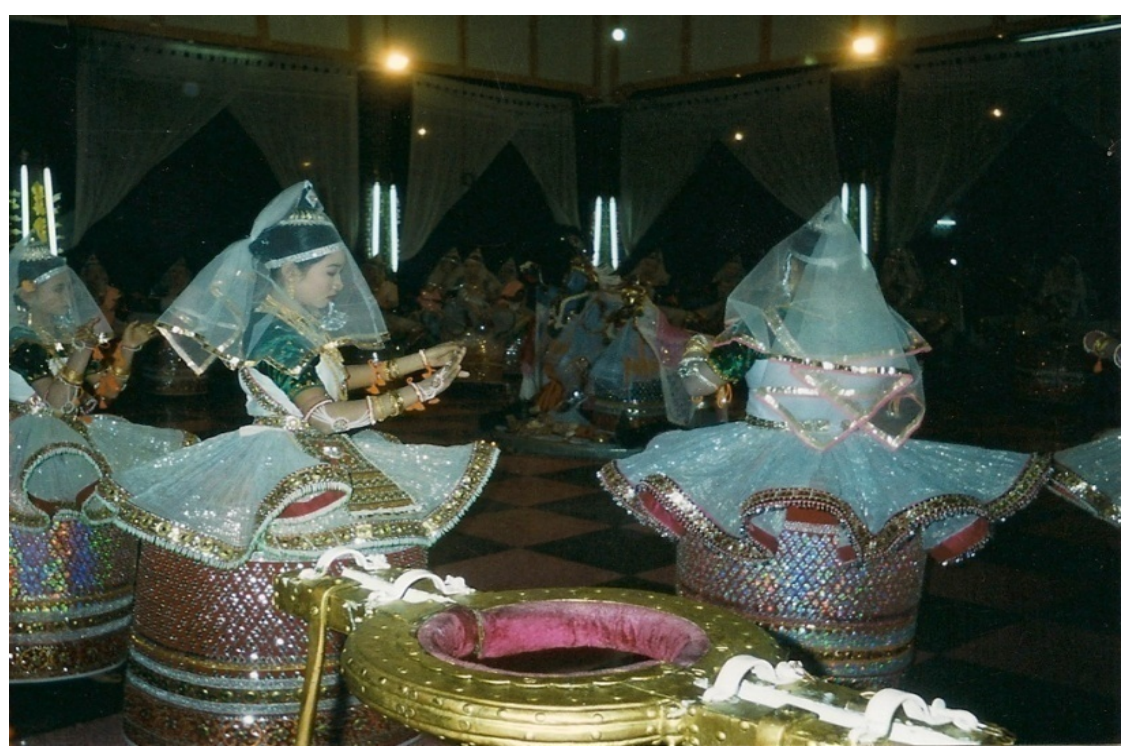

Figure 4: Maharaas at Sri Govindaji Temple

\section{THE KROM (SEQUENCE)}

1) With the beginning of Raas leela, the Raasdhari with his assistant will play the pung (mridanga) by beating the 'Raga Macha' i.e. Nuwa raga along with the sound of conch. The Sutradhari (singers) will start singing the Kanu raga with Bahon and followed by the songs of Raga taba. For the raas leela of Shri Govindaji, the songs are sung in Sanskrit, Vrajaboli and Bengali. The Sutradhari will sing Vrindavan Varnan in Tanchap Araoba, the song runs as "Aparoopa Shri Vrindavan sobha..." and again in chali tala as "Chandra Sekhara kohe Vrindavan sobha...". Next the singing of Vaishnava Bandana as "Atro sada biraj maan ShriMaddradha shrila Govindayo...".

2) In Govindaji raas, there will be no character of playing Krishna as the idol of the deity is already there in the centre of Raasmandal. Therefore, the Sutradhari will sing only the song of Krishna Abhisar as well as krishna reaching Bangshi bot. As such, there will be no dance for Krishna Abhisar. Such songs recited by the Sutradhari are starting from sloka number 1,2,3 of $1^{\text {st }}$ Adhyay of Raaspanchadhyay as "Shri Badarayanirubacha ..." to the last line "Bamadrishyam manoharam..." of sloka number 3. Then followed by Muruli-Nad. Here, the Sutra will recite beginning from the $4^{\text {th }}$ sloka i.e. "Nishamya geetam tadananga vardhanam...".

3) In the Govindaji Maharaas, the Radha and Gopi Abhisar is performed though the idol of Radha is placed at the Badhachakra. A girl in Koktumbi potloi in green colour acting as Radha comes out along with other Gopis as a form of Radha Abhisar. The Sutradhari will sing the $12^{\text {th }}$ sloka beginning with "Ta dristantikamayata..." and then followed by the song - "Jaya jaya jaya vijay nikunje..." etc. When The Gopis get Krishna they all will sit on their knees and after bowing down will remain with folded hands.

4) Then followed by Krishna ukti (lol). It is performed by a Brahmin representing as Krishna, describing about the well coming of Radha and Gopis. Here, $18^{\text {th }}, 19^{\text {th }}, 20^{\text {th }}, 21^{\text {st }}$ slokas of $1^{\text {st }}$ Adhyay of Raaspanchadhyay is recited.

5) After this the Sutradhari will sing the texts of Raas Panchadhyay starting from sloka number $28^{\text {th }}$ to $29^{\text {th }}$ of $1^{\text {st }}$ Adhyay in Chhada (without tala).

6) Then the leading Gopis representing like Lalita, Visakha, Chitralekha, Indurekha, Champakalata, Rangadevi, Tungavidya, Sudevi and Radha will recite the $31^{\text {st }}, 32^{\text {nd }}, 33^{\text {rd }}, 34^{\text {th }}, 35^{\text {th }}, 36^{\text {th }}, 37^{\text {th }}, 38^{\text {th }}, 39^{\text {th }}$ slokas of $1^{\text {st }}$ Adhyay of Raas Panchadhyay respectively. Then the Gopis will recite together the following sloka

"Prananatha suna suna

Pranabandhu he rasika nagara..."

7) It is followed by the Prarthana in chali tala. The Sutradhari sing the song meanwhile the Makok Chingbi and Mathang Chatpi perform chali dance. The song runs thus -

"Prananatha Madhav rasika sirmani..." 
8) Then comes Makok Chingbi dance. The sutra will sing thus"Nrityati Lalita Nache theiya ta ta..."

9) Then comes the episode of Gopi Lengthokpa and Jagoi Mapop. Here, the Gopis make a circle surrounding the idols of Radha Govinda. In the mapop portion the Sutradhari sing the song and the Gopis response it. The Jagoi mapop begins with the tintala in the song "Nachata Shyama Sangae Brajanari...", chali tala in the song "Jalada punja janu tarika latabali...", Menbhusana tala in the song "Birah Radha Madhap...", Tanchap tala in the song "Nija Nija Ballbha Dhu Dhati...".

10) Jagoi Mapop is followed by Bhangi Pareng Achouba. The song sung in the dance of such Bhangi beginning from the $8^{\text {th }}$ sloka i.e. "Padanya sirbhuja vidhutivi..."

$\mathrm{Up}$ to the last line of the $17^{\text {th }}$ sloka as "reme rameso Vraja sundaribhiryatharbhakah svaprativimbavibhramah" of $5^{\text {th }}$ Adhyay of Raas Panchadhyay. The song "Ta theiya theiya mridanga..." ending with "Manthara padayati Madhav iha rasa gaiye" may also be sung in place of the above Bhangi song.

11) Then comes the krishna Nartan and Radha Nartan. Since, the idol of Krishna and Radha is placed in the centre of Raasmandal, the Krishna Nartan and the Radha Nartan is not performed. Only the song sequences are sung and the Gopis danced. The Krishna Nartan begins with the Tanchap tala in the song "Shyama nrityati gayati vadayate..." etc. The Radha Nartan begins with the Mentanchap tala in the song "Chandrabadani nrityati mana mohinidhani hai hai...", tanchap tala in the song "Nachata natini gaota Natasekhar gaye...", Chali tala in the song "Taragan sanye tarapati heri...".

12) Here, the sutra will sing the song of Krishna Antardhyan as "Tabe Krishna Vrajangana jani ahamkara...”. At this time the central area of the Mandap is partially darkened to suggest the idea of disappearance of shri Krishna and Radha leaving the Gopis. Again the sutra sing- "Bhalo bhalo Yamuna nikunje rai kanu milana kje...".

13) The gopis moving around inside the raasmandali of mandap in search of Shri krishna. Here the gopi geet (gopis song) is sung as "Ha ha pranabandhu Gokulchandra kothai...", and another song as "Dekha sahki ai kon..." will be sung in chhada. Here, the sutradhari will sing as "Remetaya chatmarat atmaram pyakhandit...".

14) Then, the Sutradhari will express through the song sung when Radha Krishna appear again in the grove after the Antardhyan (disappearance) of them. This time, all the gopis will be seated on the eastern side of raasmandali. During the process of the song , the $38^{\text {th }}$ sloka in the $2^{\text {nd }}$ Adhyay of Shri Raaspanchadhyay will be recited.

15) Hence, Shrimati Radhika will recite the $39^{\text {th }}$ sloka in the $2^{\text {nd }}$ Adhyay of Shri Raaspanchadhyay to Shri Krishna. In such instant the virgin girl in the role of Radha will recite the sloka in front of the Bhadrachakra.

16) The Brahman taking the role of Krishna will recite the first line of the 40th sloka in the $2^{\text {nd }}$ Adhyay of Shri Raaspanchadhyay as "Evamuktah priyamaha skandha aruhyatamiti..."

17) Then the sutradhari in the sloka chhada will repeat the above line of the $40^{\text {th }}$ sloka and continue the line as "Tatascantardadhe Krishnah sa badhuranvatapata..."

18) Enacting as Radha the song continues as "Hayare hayare hayare haya haya , toma vine dasadiga haila andha...". Then praying to krishna. She will recite as "He deva he dayita, he bhuvanaika bandhu...". After this the $41^{\text {st }}$ sloka in the $2^{\text {nd }}$ Adhyay will be recited and will present the Abhinaya of fainting.

19) Then the sutradhari sing as "Dhire dhire chale gopi Krishna anusari....". In such instant, Radha is found surrounded by the gopis.

20) The eight sakhis now sit enact and tell Radha singing as "utha Radhe pranapriye Govinda mohini...". When they further sing as "Hare Krishna nam sarbbamantra...". Radha will come to senses.

21) The role of Radha sings as "Pranasakhi he, amake chadiya kotha gele...". Then the gopis including Radha sing in chhada as "Sakhi jhai jhai iha Yamunar jale pravesi...".

22) Then follows the song of sutradhari as "Punah pulinmagta Kalindyah Krishnabhavanah...”.

23) Next, in the form of Gopi geet the $1^{\text {st }}$ sloka in the $3^{\text {rd }}$ Adhyay of Sri Raaspanchadhyay will be recited. The gopis sing -

24) "Jayati tehadhikam janmana vrajah..."

Sri Krishna becomes Abirbhoot (re-appearance of the Lord). Sutradhari will recite the sloka numbers, $1^{\text {st }}$, $2^{\text {nd }}, 4^{\text {th }}, 5^{\text {th }}, 6^{\text {th }}, 7^{\text {th }}, 12^{\text {th }}$ and $13^{\text {th }}$ in the $4^{\text {th }}$ Adhyay of Sri Raaspanchadhyay. In such instant the raasmandali will be lighted. 
$25)$ Then the riddles among the gopis will be heard. The $16^{\text {th }}$ sloka in the $4^{\text {th }}$ Adhyay of Sri Raaspanchadhyay will be recited.

26) The Brahman in the role of Shri Krishna will recite the $17^{\text {th }}$ sloka in $4^{\text {th }}$ Adhyay of Shri Raaspanchadhyay.

27) Then follows 'Eko Gopi Eko Shyam' in which the sutradhari sing as "Gopi gopal rasa raas mandali..." in Mentanchap tala. Then the sutra sing slokas $6^{\text {th }}$ and $7^{\text {th }}$ in the $4^{\text {th }}$ Adhyay of Shri raaspanchadhyay in chali tala as "Valayanam nupuranam kingkininanca yositam ..." to the last line "Madhye maninam haimanam mahamarakato yatha..." of sloka number $7^{\text {th }}$.

28) Then comes the Gopi Vrindavan Bhangi Pareng in which the Sutradhari sing as "Matta madhukar vividha gunjara..." in Tintala Achouba.

29) Prarthana will follow with the song of sutradhari as "Jayare jayare Radha Madhav basanalankrita balaya jankrita..." in Mentanchap tala.

30) Puspanjali (offering of a handful of flowers) will follow. Here the Sutradhari and gopis also sing together in Mentanchap tala as "Eyi puspanjali jeman banjah puri samarpilu...".

Geet "Puspanjali" (Narasingh Puspanjali)

"Janame Janame jivane marane

Pranapati hao tumi natha

Bahu punyakale gouri aradhiya...."

31) After this the Brahmins will be ready for offering Aarti in which the Raasdhari, Sutradhari, Gopis, Vaishnavas and everybody present raise up during the singing of Aarti as -

"Aarti Vrajaraj Nandakumar gaot

Vrajabadhu anand bihare..."

Thus aarti (greeting of the duo) is done now and Maharaas comes to an end.

32) There is no Grihagaman (the notional taste of home going) is shown in the performance held in the mandap of Sri Govindaji.

\section{MAHARAAS AT OTHER LOCAL TEMPLES}

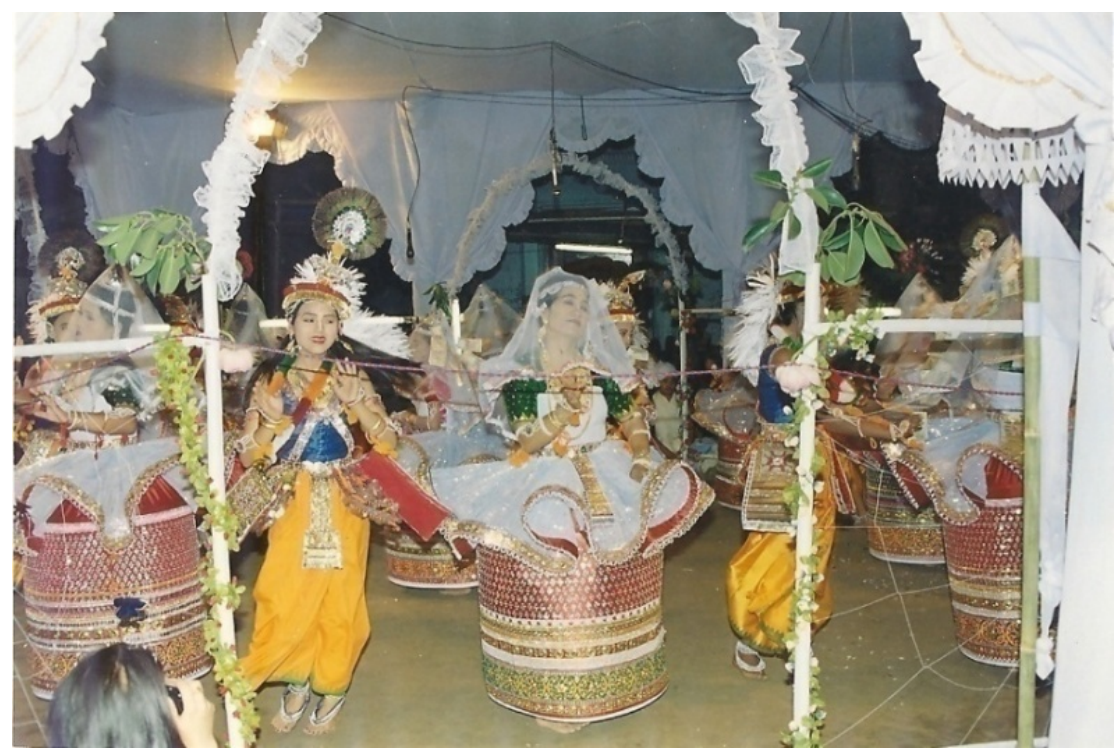

Figure 5: Performance of Maharaas at other local temple

Maharaas is performed in the mandap or pavilion attached to a temple is shown in figure No. 5 . In local areas in absence of mandap, temporary mandap is set up or erected. It is built mostly in continuation or extension of the temple, having its own codes, style and architecture. The pillars are normally made of bricks, wood or bamboo, and the roof is covered either with tin sheets or thatch (straw). The Mandap as such is constructed with great care fulfilling the required rules, as it signifies the holy place where the divine sport of Krishna and Gopis is to be performed. The exact performance space of the Raas Leela is known as Raasmandal. It is the central space of the mandap where the exact performance takes place. 
A mandap has nine posts including the central and main post called Jatra. In the Vrindavan Bhava, the eight pillars become Gopis namely - Lalita, Bisakha, Sudevi, Indurekha, Rangadevi, Chitra Champakalata and Tungavidya and the main (central) pillar stands for Radha Krishna. Through process of transformation, mental and spiritual transportation the Mandap becomes Nabadwip, the eight pillars represent the spiritual followers of Chaitanya and the pillar at the centre of mandap stands for Chaitanya himself. In a mandali it has 8 posts without the main post i.e. jatra. Even though there is not main post, a space is provided where Dhup-dip, betel nut and leaf are offered in the asana where Radha Krishna are supposed to be stationed. Thus, the details of Mandap and Mandali are very minute as these are closely associated with the performance of numerous religious and social rituals.

\section{ARRANGEMENT OF RAAS MANDAL}

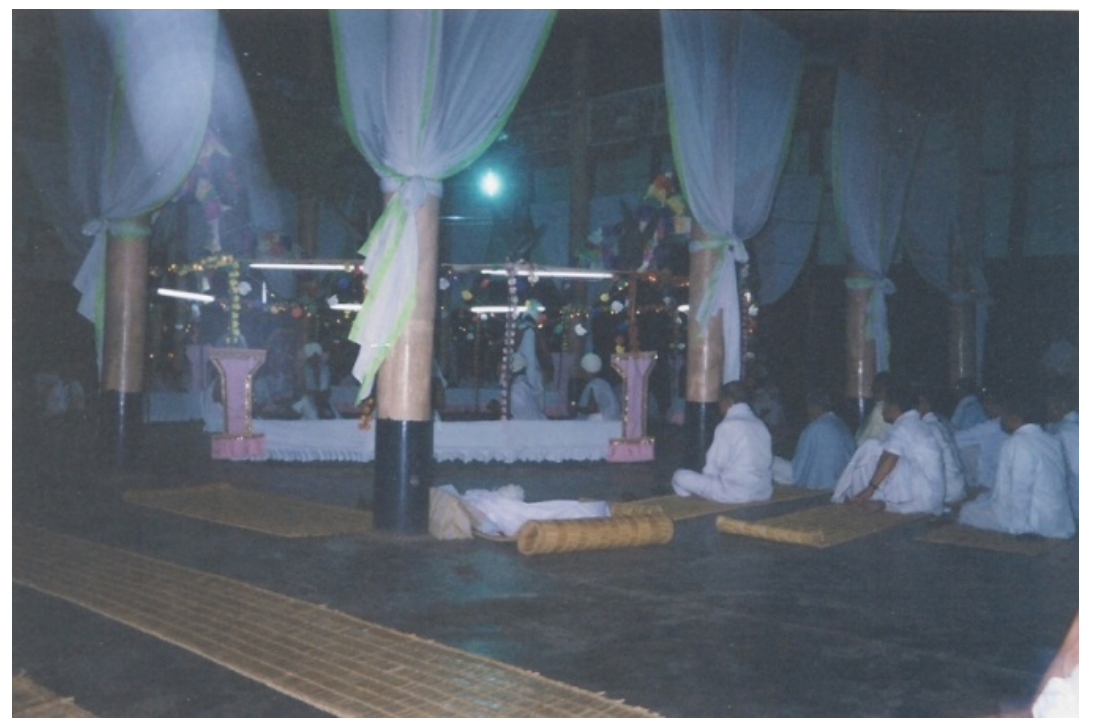

Figure 6: Raasmandal at local temple (Bijoy Govinda)

The type of the Raasmandal varies from text to text. In the Vrindavan Bhava the main playing space was centered around the dense forest of Vrindavan where a crescent shape platform with abundant sweet smelling flowers, creepers and flower - buds all around is shaped for the divine sport The present day Raasmandal is somewhat created to resemble as mentioned in the puranas with artistic specified effects. The Raasmandal of Manipuri Raasleela is slightly roundish. The Raasmandal is constructed, designed and decorated to have a realistic resemblance of the settings of Vrindavan's Raasleela spot.

The decoration of the Raas-mandal is time consuming. Thus, it begins few days prior to the performance day. The mandali is cleaned and decorated. Instances of two types of raasmandal beautification are seen. The main 12 pillars of the raasmandal are either wrapped with white clothes or with leaves (especially jackfruit tree or peepal). The ceiling is first covered with yemphak which is a mat, made of bamboo strips crossing one another or at times simply with plain white cloth. At present, movable ceiling is used.

The natural environment of the typical Raasmandal is created with inputs of creepers, artificial birds (parrots mainly) flowers, branches, etc. In the past a real parrot is kept in the Raasmandal. A dol (swing) which is required in the Raasleela performance is kept attached to the ceiling and at the right sequence it is put down. The whole beauty of the Raasleela is also enhanced with the throwing down of flowers and petals from the ceiling in sequences like aarti, prarthana and yugal aarati. A helper is engaged in arranging and dropping down the essentials from the ceiling during the performance. All the decorations are made in such a way that it should not obstruct the audience view. The realistic representation is further attempted with dropping of peacock, birds, etc. as the development or intensification of the plot demands. Women and young girls participate in making flower garlands for Raasleela.

In the past lighting is normally with big oil lamps. Nowadays, lighting generally comprises of bulbs and tube lights. Straw mats are spread out in rows in all the directions surrounding the Raasmandal for the audience. Once the preliminaries and beautification of the Raasmandal is over, it is considered or taken as Vrindavan's Nikunja forest. The Raasmandal is pure and sacred and prohibits entering it. The Vaishnava devotees identify it with the real performing space of Radha and Krishna. 
The offering of Maharaas seems rare in other local temples of Manipur except those performances in the temple complexes of Sri Govindaji (Palace Compound), Sri Bijoy Govindaji (Sagolband) and Gopinath of Ningthoukhong.

\section{DISTINCTION BETWEEN MAHARAAS OFFERED AT SRI SRI GOVINDAJI AND OTHER LOCAL TEMPLES}

Even though there is main theme between the Raas offered in the mandapa of Sri Sri Govindaji and other local temples, there are significant differences when in practice.

The differences are enumerated as:-

1) As the Raas played in the mandap of Govindaji Temple is offered by the king it is performed on the full moon day of Hiyangei i.e.Kartik. There is no permission to other localities to be offered in advance or on the same day with that of Govinda.

2) In the Raas for the Govinda, both Radha and Krishna are of idols. But in the Raas played in the localities, Radha and Krishna are characterised by the participants.

3) In the Raas of Govinda, the idols of Radha and Govinda are stationed in the Bhadra Chakra situated at the center of Raasmandal before the start of the Nupa pala. But in other localities Radha and Krishna are not stationed as they are characterised by the participants.

4) Just after the conclusion of Nupa Pala of Govinda, Kunja Aarti is offered before the beginning of the Raas. But no Aarti is offered before the beginning of the Raas in the localities.

5) For the Raas of Govinda, after the completion of singing of Sutra Raga with the chanting of sloka for the part of Krishna Abhisar .There is no dance of Krishna Abhisar. In the Raas of localities, dances are performed with the singing of songs for Krishna Abhisar by the sutra.

6) As for the Raas of Govinda, when the gopis reach near Sri krishna will recite sloka number $17-24$ of the $1^{\text {st }}$ chapter of Raas Panchadhyay i.e. "Swagatam bo mahabhaga" (the welcome address) by a representing Brahmin as Sri krishna is of idol. In the raas at localities, the person characterizing Sri krishna will chant the welcome address.

7) After the Bhangi dance, the dances of Krishna Nartan and Radha Nartan are played singing by the gopis being Radha and Krishna as idols. But for the raas in the localities Radha and Krishna come out individually and dance with their capability.

8) In the moment of Krishna Antardhyan, as the idols being stationed in the centre, it is performed by the putting off all the illuminated lights in the Mandapa. Then after completing the gopi geet, the light again illuminates at the Aberbhut of Krishna. In the local temples, Radha and Krishna being lively characters, the searching of Krishna by the gopis after the disappearance of Radha and Krishna from the centre of Raasmandal is seen completely and appearance of Krishna with Radha and further disappearance of Krishna all are seen here.

9) Thus when the concluding moment of Raas comes, for the Raas offered to Sri Govinda, the aarti is offered by the Brahmins. For the raas played in the localities, the gopis offer aarti to the characters playing Radha and Krishna.

10) In the concluding part of Raas of Sri Govindaji there is no 'griha gaman' (the notional taste of home going). For the Sri Govindaji Raas, there should be union of two idols of Radha and Krishna. There will be 'Griha Gaman' in the raas of the locality.

11) For the raas of Sri Govindaji, the moving out of the idols of Radha and Govinda from inside the Mani-Mandir up to the Bhadrachakra of Raasmandal are performed. After the performance of the Raasleela is concluded, the idols of Radha and Govinda are served by the Brahmins for shifting both the idols and moving inside the Mani-Mandir (Temple) like the same procedures as done before. Such is not done in the Raas played in the localities.

These are the distinguishing points between Maharaas offered at Sri Govindaji's and other local temples including Sri Bijoy (Bijaynath) Govindaji, Sagolband. 


\section{OBJECTIVES OF PERFORMING MAHARAAS}

Such a Raasleela having high qualities with our sincerest determination and faith if offered, it is regarded as lucky and virtuous.

For example:-

1) Pray for abundance of wealth and ability for the service to the God.

2) Someone leading (makok chingbi) the raas prays for having progeny when she has no issue.

3) Some Vaishnava devotee arrange their offsprings (descendants) to play the divine roles of Radha Govinda in the service of Raas leela praying for long lives of their offsprings.

4) Some female sinners play the roles of Gopis with deep devotion in the raas leela praying for atonement of their past sins.

The virtue of offering Raasleela is that anybody according to their determinations or wants, he/she enjoys its fruit and consequences, it is firmly believed. Practically, the children taking different roles including that of Krishna though seem inexperienced at times could not bring out the appropriate Abhinaya to the audience. But the audience sees the young children performance with utter devotion as if they are real. In such way of viewing the performance the audience attains Bhakti rasa. Generally, the elder performers taking the roles of Gopi do their Abhinaya well to express the right kind of rasa (sentiments and emotions). Thus people make their children enact the roles in raas leela as it is considered auspicious.

\section{SOURCES OF FUNDING}

This research received no specific grant from any funding agency in the public, commercial, or not-for-profit sectors.

\section{CONFLICT OF INTEREST}

The author have declared that no competing interests exist.

\section{ACKNOWLEDGMENT}

None.

\section{REFERENCES}

[1] Bharat Singh, P. Shree Shree Govindajee of Manipur. Nest Advertising and Marketing Pvt Ltd : Imphal, 2015.

[2] Iboton Singh, Phanjoubam. Manipuri Raas Amasung Atei Krishna Leelasing. Imphal, 2005.

[3] Ibochaoba Singh, Haobam. The Pre-World War - II Form of Ras Leela. Imphal, 2009.

[4] Sharma, Surchand. Bhangi in Manipuri Raas Dance. R.B.Printing House : Imphal, 1993.

[5] Sruti Bandopadhay. Manipuri Dance: An Asessment on History and presentation. Shubhi Publications: Gurgaon, 2010.

[6] Thouranisabi Devi, Ksh. Raas Makhal Amasung Nunggi Masak. Iboyaima Printers: Imphal, 2006.

[7] Tombinou Devi, Arambam. Shri Shri Govindajigi Maharaas Sheireng (Guru Amubina Thambiramba Meiteilolgi Maharaas Sheireng). Angom Ningthou Preservation and Documentation Centre: Imphal, 2013. 